\title{
Pengaruh Suku Bunga Acuan dan Nilai Kurs Tengah Valuta Asing Terhadap Return Saham
}

\author{
Ivan Pratama \\ Fakultas Ekonomi Program Studi Akuntansi-Univ.Kristen Maranatha \\ (Jl. Prof. Drg. Suria Sumantri No. 65, Bandung) \\ ivanpratamaa14@gmail.com \\ Lauw Tjun Tjun \\ Fakultas Ekonomi Program Studi Akuntansi-Univ.Kristen Maranatha \\ (J1. Prof. Drg. Suria Sumantri No. 65, Bandung) \\ lauwtjuntjun@gmail.com
}

\begin{abstract}
Inflation is one of the phenomena that indicate a monetary policy is not effective or monetary crisis is going on. It can stimulate weak of the exchange rate, declining purchasing power, as well as fluctuations in interest rate (BI Rate) which make the performance of the company may face a problem that will have an impact on the development of capital markets. Companies with good performance can attract more investors. The purpose of this research is to determine the effect of interest rate (BI Rate) and foreign exchange currency (USR-IDR) Bank of Indonesia to stock returns. The sample selection using purposive sampling technique. The samples are banking companies list on Indonesia Stock Exchange in 2012-2015 with some criteria. This research uses secondary data from Bank of Indonesia data reports in 2012-2015 and banking companies stock price reportin 2012-2015. The analysis model is multiple linear regression with help from SPSS and the significance level is 0.05. Results of this research is that interest rate (BI Rate) and foreign exchange currency (USR-IDR) Bank of Indonesia simultaneous effect on stock returns with effect level of $8.6 \%$ and a significance value of 0.029. But partially, they have no effect on stock returns.
\end{abstract}

Keywords: Interest Rate (BI Rate), Foreign Exchange Currency (USD-IDR), and Stock Return.

\section{Pendahuluan}

Masalah inflasi di Indonesia ternyata bukan saja merupakan fenomena jangka pendek, tetapi juga merupakan fenomena jangka panjang. Dalam arti, bahwa inflasi di Indonesia bukan semata-mata hanya disebabkan oleh gagalnya pelaksanaan kebijaksanaan di sektor moneter oleh pemerintah, yang seringkali dilakukan untuk tujuan menstabilkan fluktuasi tingkat harga umum dalam jangka pendek, tetapi juga mengindikasikan masih adanya hambatan-hambatan struktural dalam perekonomian Indonesia yang belum sepenuhnya dapat diatasi.

Menurut Bank Indonesia (2013), kestabilan inflasi merupakan prasyarat bagi pertumbuhan ekonomi yang berkesinambungan yang pada akhirnya memberikan manfaat bagi peningkatan kesejahteraan masyarakat. Pentingnya pengendalian inflasi didasarkan pada pertimbangan bahwa inflasi yang tinggi dan tidak stabil memberikan dampak negatif kepada kondisi sosial ekonomi masyarakat. Suku bunga dan nilai kurs menjadi tidak stabil akibat adanya inflasi, inflasi juga memiliki dampak terhadap suku bunga dan nilai kurs, yang tidak kalah penting hal ini berimbas pada sektor moneter lain, yaitu pasar modal.

Pasar modal memiliki peran penting bagi perekonomian suatu negara karena pasar modal menjalankan dua fungsi, yaitu pertama sebagai sarana bagi pendanaan usaha atau sebagai sarana bagi perusahaan untuk mendapatkan dana dari masyarakat pemodal atau investor (Suad Husnan, 2004). Dana yang diperoleh dari pasar modal dapat digunakan untuk pengembangan usaha, ekspansi, penambahan modal kerja dan lain-lain.

Kedua pasar modal menjadi sarana bagi masyarakat untuk berinvestasi pada instrumen 
keuangan seperti saham, obligasi, reksadana, dan lainlain. Dengan demikian, masyarakat dapat menempatkan dana yang dimilikinya sesuai dengan karakteristik keuntungan dan risiko masing-masing instrumen keuangan di atas.

Produk dari pasar modal yang diperdagangkan di pasar modal umumnya dibedakan menjadi dua, yaitu surat berharga yang berbentuk kepemilikan dan surat berharga yang berbentuk hutang. Beberapa produk yang tersedia di pasar modal adalah reksadana, waran, obligasi, right issue, dan juga salah satunya adalah saham. Saham adalah tanda penyertaan atau pemilikan seseorang atau badan dalam suatu perusahaan. Pembeli saham memiliki hak untuk ikut serta menjadi pemilik perusahaan dan apabila perusahaan tersebut mengalami surplus, maka para pemegang saham dapat menerima return saham berupa dividend yield atau capital gain.

Investor, sebagai pembeli saham sekaligus pemilik perusahaan, tentunya mengharapkan pengembalian (return) yang besar dari perusahaan yang dimilikinya. Banyak investor, baik investor muda maupun investor yang sudah berpengalaman, berbelanja saham dalam pasar modal. Seperti layaknya pasar, investor perlu dengan cermat memilih saham yang dijajakan di pasar modal agar sahamsaham yang dibeli dapat membuahkan hasil yang diharapkan. Maka dari itu, analisis fundamental yang berkaitan dengan kondisi makro Indonesia memiliki peran penting dalam proses pembelian saham dalam pasar modal. Pergerakan harga saham bisa dijadikan patokan untuk melihat penurunan atau kenaikan return saham yang diperoleh. Harga saham yang meningkat menunjukkan bahwa minat pasar semakin tinggi akan saham tersebut, dengan kata lain saham tersebut semakin bernilai di pasar.

Menurut Erawati dan Llewelyin (2002), suku bunga juga merupakan salah satu faktor yang penting dalam perekonomian suatu negara karena sangat berpengaruh terhadap "kesehatan" suatu perekonomian. Hal ini tidak hanya mempengaruhi keinginan konsumen untuk membelanjakan ataupun menabungkan uangnya tetapi juga mempengaruhi dunia usaha dalam mengambil keputusan. Oleh karena itu tingkat suku bunga mempunyai pengaruh yang sangat luas, tidak hanya pada sektor moneter, melainkan juga pada sektor riil, sektor ketenagakerjaan, bahkan sektor internasional. Berfluktuasinya tingkat inflasi di Indonesia mengakibatkan semakin sulitnya penegendalian atas fenomena tersebut.

Nilai kurs juga memiliki dampak terkait inflasi yang mengkibatkan terkenanya dampak terhadap kinerja perusahaan, ketika nilai mata uang disuatu negara melemah atas negara lain maka akan sangat terlihat dampaknya ialah harga dari barang atau jasa impor. Karena harga atas barang atau jasa impor dipatok dengan dengan mata uang negara asal (negara pengekspor).
Penelitian-penelitian ini penting untuk dilakukan karena dapat memberi dampak positif untuk beberapa pihak. Investor dapat melakukan analisis fundamental yang berkaitan dengan kondisi makro ekonomi Indonesia dengan lebih efisien dan efektif. Selain bagi investor, penelitian ini juga berguna bagi perusahaan, khususnya perusahaan perbankan yang membagi kepemilikannya melalui saham, agar dapat menjadi referensi dalam pengambilan keputusan atas variabel-variabel yang dapat melibatkan pergerakan return saham.

Beberapa peneliti telah melakukan penelitian mengenai kebijakan monetermakro ekonomi Indonesia yang mungkin dapat mempengaruhi return saham. Namun, beberapa penelitian tersebut menunjukkan hasil yang menarik, dimana timbul ketidakkonsistenan antar peneliti dalam variabel yang sama. Ardian Agung Witjaksono (2010) mengatakan bahwa suku bunga acuan dan nilai kurs memiliki pengaruh negatif terhadap return saham dan hasil ini kontradiksi dengan penelitian dari Suramaya (2012) dan Achmad Reza (2013) yang mengatakan bahwa suku bunga auan dan nilai kurs tidak memiliki pengaruh positif terhadap return saham.

Dengan ketidakkonsistenan hasil-hasil penelitian terdahulu, penulis tertarik untuk menguji kembali pengaruh suku bunga acuan dan nilai kurs tengah Bank Indonesia terhadap return saham pada perusahaan-perusahaan perbankan yang terdaftar di Bursa Efek Indonesia (BEI). Penelitian ini juga dilakukan untuk menguji konsistensi hasil dari penelitian sebelumnya dengan harapan bahwa hasil dari penelitian ini dapat menjadi pertimbangan dalam pembuatan keputusan.

Perumusan masalah adalah sebagai berikut.

1. Apakah suku bunga acuan secara parsial berpengaruh terhadap return saham perusahaan?

2. Apakah nilai kurs tengah valuta asing (USDIDR) Bank Indonesia secara parsial berpengaruh terhadap return saham perusahaan?

3. Apakah suku bunga acuan dan nilai kurs tengah Bank Indonesia secara simultan berpengaruh terhadap return saham perusahaan?

Sedangkan tujuan penelitian adalah untuk mengetahui

1. Pengaruh Tingkat Suku Bunga Acuan (BI Rate) terhadap return saham perusahaan.

2. Pengaruh Kurs Tengah Valuta Asing (USDIDR) Bank Indonesia terhadap return saham perusahaan.

3. Pengaruh Tingkat Suku Bunga Acuan (BI Rate) dan Kurs Tengah Valuta Asing (USD-IDR) Bank Indonesia terhadap return saham perusahaan secara simultan. 


\section{Kajian Pustaka}

\section{Definisi Inflasi}

Menurut Rimsky K. Judisseno (2010:2) mengatakan bahwa inflasi merupakan salah satu dari peristiwa moneter yang menunjukkan suatu kecenderungan akan menaikkan harga barang-barang secara umum yang menyebabkan terjadinya penurunan harga barang. Sedangkan pengertian inflasi menurut Sadano Sukirno (2012:3), mengatakan dalam bukunya makro ekonomi bahwa pengertian inflasi adalah suatu proses kenaikan harga-harga yang berlaku dalam suatu perekonomian. Salah satu penyebab dari terjadinya inflasi adalah berbagai faktor yang memengaruhi dalam mekanisme pasar.

\section{Pengertian Suku Bunga Acuan (BI Rate)}

Menurut Bank Indonesia, BI Rate adalah suku bunga kebijakan yang mencerminkan sikap atau stance kebijakan moneter yang ditetapkan oleh bank Indonesia dan diumumkan kepada publik. Fungsi dari BI Rate diumumkan oleh Dewan Gubernur Bank Indonesia setiap Rapat Dewan Gubernur bulanan dan diimplementasikan pada operasi moneter yang dilakukan Bank Indonesia melalui pengelolaan likuiditas (liquidity management) di pasar uang untuk mencapai sasaran operasional kebijakan moneter.

\section{Definisi Nilai Kurs}

Menurut Musdholifah \& Tony (2007), nilai tukar atau kurs adalah perbandingan antara harga mata uang suatu negara dengan mata uang negara lain. Sedangkan, menurut Triyono (2008) kurs (exchange rate) adalah pertukaran antara dua mata uang yang berbeda, yaitu merupakan perbandingan nilai atau harga antara kedua mata uang tersebut.

Jadi, nilai tukar rupiah adalah suatu perbandingan antara nilai mata uang suatu negara dengan negara lain. Heru (2008) menyatakan bahwa nilai tukar mencerminkan keseimbangan permintaan dan penawaran terhadap mata uang dalam negeri maupun mata uang asing (USD).

\section{Definisi Pasar Modal}

Dalam Undang-Undang nomor 8 (1995) tentang pasar modal, pasar modal didefinisikan sebagai kegiatan yang berhubungan dengan penawaran umum dan perdagangan efek, perusahaan publik yang berkaitan dengan efek yang diterbitkannya, serta lembaga dan profesi yang berkaitan dengan efek.

Menurut Tandelilin (2010:26), pasar modal adalah pertemuan pihak yang memiliki kelebihan dana dengan pihak yang membutuhkan dana dengan cara memperjualbelikan sekuritas/efek. Dengan demikian, pasar modal juga bisa diartikan sebagai pasar untuk memperjualbelikan sekuritas yang umumnya memiliki umur lebih dari satu tahun.

\section{Definisi Return Saham}

Menurut Tandelilin (2010:102), return saham merupakan salah satu faktor yang memotivasi investor berinvestasi dan juga merupakan imbalan atas keberanian investor menanggung risiko atas investasi yang dilakukannya. Tanpa adanya tingkat keuntungan dalam berinvestasi, maka investor tidak akan melakukan investasi. Sedangkan menurut Brigham dan Houston (2006:215), return atau tingkat pengembalian adalah selisih antara jumlah yang diterima dan jumlah yang diinvestasikan, dibagi dengan jumlah yang diinvestasikan.

\section{Rerangka Pemikiran}

Menurut Bank Indonesia, BI Rate adalah suku bunga kebijakan yang mencerminkan sikap atau stance kebijakan moneter yang ditetapkan oleh bank Indonesia dan diumumkan kepada publik.

BI Rate merupakan kebijakan moneter yang penting dalam mengatur pertumbuhan sektor moneter di Indonesia. Salah satu sektor moneter yang berkaitan adalah pasar modal. Ketika BI Rate naik, investor saham akan mensyaratkan keuntungan yang lebih tinggi pula pada investasi saham. Artinya, mereka hanya bersedia membeli saham pada harga lebih rendah dibandingkan sebelum ada kenaikan $B I$ rate. Akibatnya, secara teoritis, pasca kenaikan suku bunga, harga saham cenderung menurun.

Seringkali kenaikan $B I$ rate berdampak positif, dan juga berdampak negatif. Namun harus dicatat, selain faktor kenaikan suku bunga, masih ada faktor lain yang mempengaruhi harga saham. Artinya, dampak negatif kenaikan $B I$ rate terhadap harga saham lebih nyata pada saat kondisi pasar modal sedang krisis.

Dapat diartikan, kenaikan suku bunga terhadap harga pasar saham bergantung pada kemampuan perusahaan menghasilkan laba. Bagi perusahaan, kenaikan suku bunga akan meningkatkan beban bunga. Jika pendapatan tidak naik, perusahaan akan mengalami penurunan laba. BI rate akan menaikkan biaya modal perusahaan (weighted average cost of capital atau WACC), yang terdiri atas biaya ekuitas dan biaya utang.

Nilai kurs valuta asing (USD-IDR) memiliki hubungan dengan pasar modal. Salah satu hal yang terkait dengan pasar saham adalah keluarnya investor asing dari pasar saham. Investor asing yang menjual saham yang dimiliki di Indonesia, lalu hasil penjualan saham itu ditukarkan ke USD dan kemudian dana tersebut keluar dari Indonesia. Dengan demikian, ketika investor asing melepas saham, berdampak pada penurunan indeks harga saham. Lalu hasil penjualan saham tersebut dialihkan untuk membeli USD. Itu salah satu penyebab harga saham turun dan nilai rupiah juga turun. Harga saham turun atau naik dapat memengaruhi tingkat pengembalian (return) saham.

Berdasarkan penelitian terdahulu dan kerangka teori yang telah peneliti sampaikan 
sebelumnya, maka peneliti menyajikan rerangka pemikiran sebagai berikut:

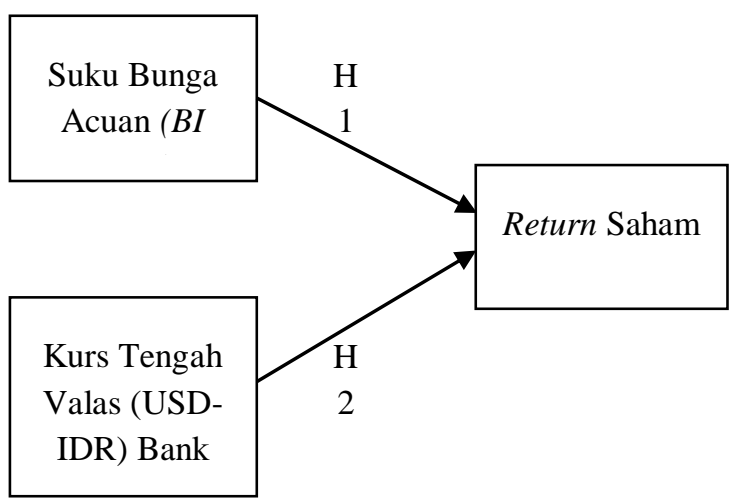

Gambar 2.2

Model Penelitian

\section{Metode Penelitian}

Penelitian ini menggunakan non-probability sampling dengan metode purposive sampling. Menurut Suliyanto (2009:124), non-probability sampling merupakan metode pengambilan sampel yang mana tiap anggota populasi tidak mempunyai kesempatan yang sama untuk dijadikan sampel. Pengambilan sampel dengan non-probability sampling karena populasi diketahui tetapi peneliti memiliki kriteria tertentu. Menurut Hartono (2014:98), purposive sampling dilakukan dengan mengambil sampel dari populasi berdasarkan suatu kriteria tertentu. Kriteria yang digunakan dapat berdasarkan pertimbangan (judgment) tertentu atau jatah (quota) tertentu.

Teknik pengumpulan data yang digunakan dalam penelitian ini adalah teknik pengumpulan data arsip (archival). Data arsip dapat berupa data primer dan data sekunder. Data primer bisa didapat dengan menggunakan teknik pengumpulan data analisis isi (content analysis), sedangkan untuk data sekunder, teknik pengumpulan data yang dapat digunakan adalah teknik pengumpulan data di basis data (Hartono, 2014:101).

Metode analisis data yang digunakan dalam penelitian ini yaitu regresi linear berganda. Regresi berganda (multiple regression) adalah model regresi yang terdiri dari lebih dari satu variabel independen (Widarjono, 2013:59). Dalam penelitian ini, variabel independen yang digunakan yaitu suku bunga acuan (BI Rate) dan kurs tengah valas (USD-IDR) Bank Indonesia, dengan variabel dependen return saham.

\section{Pembahasan}

\section{Pengaruh Suku Bunga Acuan Terhadap Return Saham}

Secara teoritis suku bunga acuan berpengaruh terhadap return saham. Untuk itu, hipotesis statistik yang digunakan dalam pengujian ini adalah sebagai berikut:

$H_{0}: \beta_{1}=0 \quad$ Suku bunga acuan tidak memiliki pengaruh terhadap return saham.

$H_{0}: \beta_{1} \neq 0 \quad$ Suku bunga acuan memiliki pengaruh terhadap return saham.

Untuk menguji hipotesis di atas terlebih dahulu nilai t-hitung untuk koefisien regresi variabel suku bunga acuan (BI Rate) perlu diperoleh, seperti yang ada pada tabel 4.7 diperoleh nilai t-hitung sebesar -1.210, kemudian untuk nilai siginifikansi diperoleh sebesar 0.231 .

Kriteria pengujian dua sisi adalah sebagai berikut:

Nilai Signifikansi $\leq$ Taraf Signifikansi $(\alpha): H_{0}$ Ditolak Nilai Signifikansi $>$ Taraf Signifikansi $(\alpha): H_{0}$ Diterima

Maka dapat disimpulkan bahwa $H_{0}$ diterima, karena nilai signifikansi yang diperoleh sebesar 0.231 lebih besar daripada taraf signifikansi sebesar 0.05. $H_{0}$ diterima artinya suku bunga acuan (BI Rate) tidak mempunyai pengaruh terhadap return saham. Hal ini mungkin terjadi disebabkan oleh suku bunga acuan yang merupakan kebijakan moneter dari bank Indonesia tidak terlalu dijadikan tolok ukur dalam menargetkan hasil return yang ingin didapat.

Angka suku bunga acuan sebenarnya memengaruhi minat investor dalam menginvestasikan dananya di Indonesia, akan tetapi pengaruh tersebut lebih kepada menyebabkan fluktuasi harga saham karena adanya kebijakan yang secara jangka panjang memengaruhi kinerja emiten. Akan tetapi suku bunga acuan tidak secara langsung memengaruhi fluktuasi return saham.

Hasil dari penelitian ini mendukung hasil penelitian yang dilakukan oleh Suramaya (2012) yang menyatakan bahwa suku bunga acuan tidak berpengaruh secara langsung terhadap return saham. Namun, hasil penelitian ini bertolak belakang dengan hasil penelitian yang dilakukan oleh Akbar Faoriko (2013) yang menyatakan bahwa BI Rate memiliki pengaruh negative terhadap return saham.

Pengaruh Kurs Tengah Valuta Asing bank Indonesia Terhadap Return Saham

Secara teoritis kurs tengah valuta asing bank Indonesia berpengaruh terhadap return saham. Untuk itu, hipotesis statistik yang digunakan dalam pengujian ini adalah sebagai berikut:

$H_{0}: \beta_{1}=0 \quad$ Kurs Tengah Valuta Asing bank Indonesia tidak memiliki pengaruh terhadap return saham. 
$H_{0}: \beta_{1} \neq 0 \quad$ Kurs Tengah Valuta Asing bank Indonesia memiliki pengaruh terhadap return saham.

Untuk menguji hipotesis di atas terlebih dahulu nilai thitung untuk koefisien regresi variabel EVA perlu diperoleh, seperti yang ada pada tabel 4.7 diperoleh nilai t-hitung sebesar -0.850 , kemudian untuk nilai siginifikansi diperoleh sebesar 0.399 .

Kriteria pengujian dua sisi adalah sebagai berikut:

Nilai Signifikansi $\leq$ Taraf Signifikansi $(\alpha): H_{0}$ Ditolak

Nilai Signifikansi $>$ Taraf Signifikansi $(\alpha): H_{0}$ Diterima

Maka dapat disimpulkan bahwa $H_{0}$ diterima, karena nilai signifikansi yang diperoleh sebesar 0.399 lebih besar daripada taraf signifikansi sebesar 0.05 . $H_{0}$ diterima artinya Kurs Tengah Valuta Asing bank Indonesia tidak memiliki pengaruh terhadap return saham. Hal ini mungkin disebabkan karena perhitungan dan manfaat Kurs Tengah Valuta Asing bank Indonesia tidak menjadi tolok ukur bagi investor dalam melakukan investasi saham dalam rangka mendapatkan return sebesar-besarnya, nilai kurs ini berkaitan dengan kinerja emiten yang banyak melakukan transaksi dalam valuta asing khususnya USD sehingga dampaknya akan terasa secara jangka panjang, tentunya hal tersebut membuat nilai kurs tidak serta merta langsung memengaruhi return saham dalam pengambilan keputusan dalam berinvestasi.

Hasil dari penelitian ini mendukung hasil penelitian yang dilakukan oleh Achmad Reza (2013) yang menyatakan bahwa nilai tukar rupiah terhadap USD tidak berpengaruh secara signifikan terhadap return saham.

\section{Pengaruh Simultan}

Berdasarkan hasil pengujian, didapatkan sig. sebesar 0.029, lebih kecil dari pada taraf signifikansi sebesar 0.05. Berdasarkan kriteria karena sig. lebih kecil dari pada alpha, maka $\mathrm{H}_{0}$ ditolak yang berarti terdapat pengaruh simultan dari variabel suku bunga acuan dan kurs tengah valuta asing (USD-IDR) terhadap return saham.

Secara teori, investor mengharapkan return yang sebesar-besarnya dalam melakukan investasi. Proses pemilihan investasi dalam pasar modal tak luput dari perusahaan yang memiliki income yang besar, karena dapat menentukan besarnya dividen yang merupakan bagian dari return saham, dapat ditentukan juga dari income perusahaan.

Besarnya pengaruh antara kedua variabel tersebut dapat dilihat dari nilai koefisien determinasi. Koefisien determinasi $\left(R^{2}\right)$ digunakan untuk mengukur seberapa jauh kemampuan model dalam menerangkan variasi variabel dependen (Ghozali, 2011:202). Berdasarkan hasil pengujian, return saham sebesar $8.6 \%$ dipengaruhi oleh suku bunga acuan dan kurs tengah valas bank Indonesia, sedangkan sisanya yaitu sebesar $91.4 \%$ dipengaruhi oleh faktor lain di luar variabel penelitian ini.

\section{Simpulan, Keterbatasan, dan Saran}

\section{Simpulan}

Tujuan penelitian ini adalah untuk mengetahui pengaruh dari kebijakan makro pemerintah Indonesia dan nilai tukar mata uang asing yang diperdagangkan dengan menggunakan variabel suku bunga acuan (BI Rate) dan nilai kurs tengah valuta asing (USD-IDR) bank Indonesia terhadap return saham. Berdasarkan hasil pengujian statistik dengan menggunakan metode regresi linier berganda pada perusahaan perbankan yang terdaftar di Bursa Efek Indonesia (BEI) tahun 2012-2015, dapat diambil simpulan sebagai berikut:

a. Variabel suku bunga acuan (BI Rate) tidak mempunyai pengaruh terhadap return saham. Hal ini mungkin terjadi disebabkan oleh suku bunga acuan yang merupakan kebijakan moneter dari bank Indonesia tidak terlalu dijadikan tolok ukur dalam menargetkan hasil return yang ingin didapat.

b. Variabel nilai kurs tengah valuta asing (USDIDR) bank Indonesia tidak mempunyai pengaruh terhadap return saham. Hal ini mungkin disebabkan karena perhitungan dan manfaat kurs tengah valuta asing bank Indonesia tidak menjadi panduan utama bagi investor dalam melakukan investasi di pasar modal.

c. Variabel suku bunga acuan (BI Rate) dan nilai kurs tengah valas (USD-IDR) bank Indonesia secara simultan mempunyai pengaruh terhadap return saham.

\section{Keterbatasan}

Penelitian ini memiliki beberapa keterbatasan, yaitu: Penelitian ini memiliki beberapa keterbatasan, yaitu:

1. Perusahaan yang dipilih menjadi sampel dalam penelitian ini hanya 15 perusahaan perbankan dari populasi sebanyak 43 perusahaan perbankan yang terdaftar di BEI selama periode tahun 20122015.

2. Variabel dalam periode ini hanya menggunakan suku bunga acuan (BI Rate) dan nilai kurs tengah valas (USD-IDR) bank Indonesia saja sebagai variabel independen, padahal masih terdapat variabel lain yang dapat digunakan untuk mengukur kebijakan makro yang dikeluarkan oleh pemerintah Indonesia seperti pemberian batas kredit, indeks saham negara lain, tingkat inflasi, tingkat pengangguran, dll.

\section{Saran}

Dari hasil penelitian ini, peneliti mencoba untuk memberikan beberapa saran yaitu sebagai berikut:

1. Peneliti selanjutnya dapat mengembangkan dengan menambah jumlah sampel dan periode 
pengamatan sehingga hasil yang diperoleh lebih mencerminkan kondisi sebenarnya di Bursa Efek Indonesia.

2. Peneliti selanjutnya dapat menambahkan variabel pengaruh yang digunakan, tidak hanya menggunakan suku bunga acuan dan nilai kurs tengah saja sebagai variabel independen, tetapi bisa menambahkan variabel lain seperti pemberian batas kredit, indeks saham negara lain, tingkat inflasi, tingkat pengangguran, dll.

3. Investor dalam pengambilan keputusan investasi di Bursa Efek Indonesia (BEI) hendaknya tidak hanya memperhatikan faktor-faktor kondisi makro di Indonesia saja, tetapi memperhatikan juga faktor kondisi kinerja perusahaan yang diukur berdasarkan rasio-rasio yang memberikan dampak terhadap pasar modal.

\section{Daftar Pustaka}

Alwi, I. Z. (2008). Pasar Modal Teori dan Aplikasi. Jakarta: Yayasan Pancur Siwah.

Arifin, I. \& Wagiana, G. H. (2009). Membuka Cakrawala Ekonomi 2. Bandung: PT Setia Purna Inves.

Brealey, R. A., Myers, S. C., Allen, F. (2014). Principles of Corporate Finance. Maidenhead: McGraw-Hill Education.

Brigham, E. F. \& Houston, J. F. (2006). Fundamentals of Financial Management. $8^{\text {th }}$ Edition. United States of America: Cengage South-Western.

Darmadji, T. \& Fakhruddin, H. M. (2001). Pasar Modal di Indonesia. Jakarta: Salemba Empat.

Faoriko, Akbar. (2013). Pengaruh Inflasi, Suku Bunga Dan Nilai Tukar Rupiah terhadap

Return Saham Di Bursa Efek Indonesia. Diakses pada Februari 8,2017. Skripsi. UNY Fakultas Ekonomi.

Ghozali, I. (2011). Aplikasi Analisis Multivariate dengan Program IBM SPSS 19. Edisi Kelima. Semarang: Badan Penerbit Universitas Diponegoro.

Hartono, J. (2010). Teori Portofolio dan Analisis Investasi. Edisi Ketujuh. BPFE. Yogyakarta.

Hartono, J. (2014). Metodologi Penelitian Bisnis: Salah Kaprah dan Pengalaman-Pengalaman. Edisi Keenam. Yogyakarta: BPFEYOGYAKARTA.

Juliandi, A., Irfan, dan Manurung, S. (2014). Metodologi Penelitian Bisnis Konsep dan Aplikasi. Medan: UMSU PRESS.

Kasmir. (2008). Bank dan Lembaga Keuangan Lainnya. Jakarta: Raja Grafindo Persada.

Kewal, S. S (2012). Pengaruh Inflasi, Suku Bunga, Kurs, Dan Pertumbuhan PDB Terhadap Indeks Harga Saham Gabungan. Vol 8. Nomor 1: Jurnal Economica
Manurung, A. H. (2013). Teori Investasi: Konsep dan Empiris. Jakarta: PT Adler Manurung Press.

Martalena \& Malinda. (2011). Pengantar Pasar Modal. Yogyakarta: Andi.

Maulana, R. M. (2013). Analisis Pengaruh Perubahan BI Rate, Nilai Tukar Rupiah Terhadap Dolar, Inflasi, IHSG dan Jumlah Uang Beredar (M2) Terhadap Tingkat Pengembalian Saham PT. Bank Mandiri (Persero) Tbk. Diakses pada tanggal Februari, 11,2017. Jurnal. UIN Jakarta.

May, E. (2011). Smart Traders Not Gamblers. Jakarta: Gramedia.

Nugroho, B. A. (2005). Strategi Jitu Memilih Statistik Penelitian dengan SPSS. Yogyakarta: Andi.

Sugiyono. (2013). Metode Penelitian Pendidikan (Pendekatan Kuantitatif, kualitatif, dan $R \& D)$. Bandung: Alfabeta.

Suliyanto. (2009). Metode Riset Bisnis. Yogyakarta: Andi.

Sunariyah. (2004). Pengantar Pengetahuan Pasar Modal. Edisi 4. Yogyakarta: Akademi Manajemen Perusahaan YKPN.

Tandelilin, E. (2010). Portofolio dan Investasi. Yogyakarta: Kanisius.

Undang-Undang Pasar Modal Nomor 8 Tahun 1995 Tentang Pasar Modal.

Witjaksono, A. A. (2010). Analisis Pengaruh Tingkat Suku Bunga SBI, Harga Minyak Dunia, Harga Emas Dunia, Kurs Rupiah, Indeks Nikkei 225, dan Indeks Dow Jones terhadap IHSG. Diakses pada Januari 20,2017. Thesis. Undip Magister Manajemen.

Bank Indonesia www.bi.go.id diakses tanggal 20 Februari 2017.

Bursa Efek Indonesia www.idx.co.id diakses tanggal 23 Februari 2017.

Yahoo Finance www.yahoofinance.com diakses tanggal 25 Februari 2017. 